\title{
Jamming Imperialism: Māori Radio and Postcolonial New Zealand
}

\begin{abstract}
New Zealand as a nation state was born imperial with the I840 Treaty of Waitangi. The Treaty established a partnership between Māori, the indigenous people, and the British Crown. The Treaty underpins all aspects of modern New Zealand. New Zealand's history has been one of colonisation with Māori being displaced, despoiled, and deprived of their land, language, and culture. In line with this history of imperial control, radio broadcasting in New Zealand developed according to foreign models. A British-styled BBC model predominated until the I980s when the wholesale adaptation of neoliberal ideologies saw New Zealand's media restructured along commercial lines. At the same time, there was a resurgence and revitalisation of Māori culture and influence in New Zealand based around the Treaty of Waitangi. This article outlines the roles of imperialism in the development of New Zealand radio before analysing the rise of Māori broadcasting as a counter-imperial response along with the increasing importance played the Māori language (Te Reo Māori) in New Zealand's postcolonial media culture.
\end{abstract}

KEYwords: Māori radio, Māori language, New Zealand, imperialism, media history, postcolonialism

New Zealanders awoke on the $\mathrm{I}^{\text {st }}$ September I9I4 to find their newspapers exulting in the capture of German Samoa. A New Zealand expeditionary force had seized the colony with no loss of life on 29 August. ${ }^{\mathrm{I}}$ It was a source of great pride that New Zealand was the first dominion to offer help to Great Britain and then the first to occupy any German territory. Samoa had become a German protectorate in I900 as part of the imperial colonial competition among the European powers. What made this small group of islands in the remoteness of the Pacific important in I9I4 was the presence of a large radio station. This transmitter could send Morse signals to Berlin and allowed the German naval command to communicate with the warships it had deployed to the Pacific. ${ }^{2}$ New Zealand had struck a blow against one imperial power for another. As James Allen, Minster of Defence, stated: 'We have simply done our duty as part of the Empire (...) and now our duty is to hold Samoa for the Imperial Government.'3 In I9I4, New Zealand's duty was always first and foremost to the 'Imperial Government' in London. 


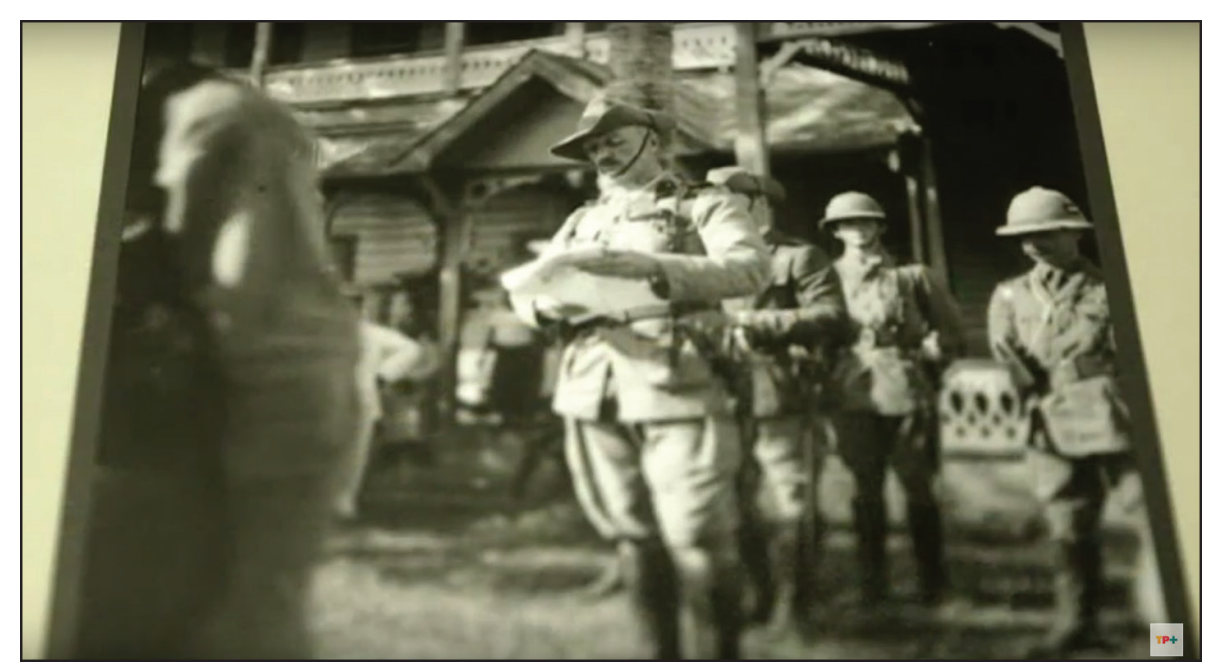

Figure 1. “Tagata Pasifika”, TVNZ's Pacific news show, reports the 1914 invasion of Samoa.

The seizure of the German radio station in Samoa encapsulates the nature of the imperial era; two European super powers seize territory far from their homelands in the name of strategic necessity and with no account or consideration of local interests or wishes. The strategic necessity in this case concerned communication technology rather than natural resources. New Zealand newspapers assured readers that capturing the wireless station had stymied Germany's global communications and added a vital link to the 'Imperial Chain' of British stations that joined the Empire with London. 4 This chain was more fable than fact in I9I4 but the message about the potential importance of wireless communication for imperialism had been received loud and clear very early on even if the vision was way beyond the contemporary technology's capabilities. ${ }^{5}$

All this seems very clear - radio, wireless, imperialism, empire, colonial - but these words are complex with many hues of meaning and they cast many long historiographical shadows. Discussions of imperialism as a historiographical category always carry a throat clearing series of caveats that point to the ambiguities, dangers, treacheries, and fault lines of the word. This article is no exception. The two opening paragraphs are framed as a nationbased narrative that places New Zealand in the context of imperial rivalry. It ascribes proimperial attitudes to the 'imagined community' of New Zealand on the grounds of an official voice quoted in printed press. ${ }^{6}$ This narrative may seem transparent and straightforward but writing history in New Zealand through, and about, colonialism, empire, nationalism, and the media is complex and multi-layered. The country's history is an imperial one that saw Māori - the land's original inhabitants - displaced, despoiled, and deprived of their lands and culture. ${ }^{7}$

New Zealand historians Katie Pickles and Catharine Coleborne briskly summarise much of New Zealand historiography about the state and empire in the introduction to a recent volume on New Zealand itself as an imperial centre. They write that the colonial and postcolonial approaches emphasise the core/periphery dualism with New Zealand on the edge: 
Meanwhile, nation-centred approaches have tended to under-emphasise the connections between New Zealand and the rest of the world (...) there is now a literature that traverses nation and empire, variously placing New Zealand as part of a 'British world', a 'Tasman world', an 'Anglo world', and networked 'webs of empire'. 8

The importance of decentring the nation state as a central category of New Zealand historical interpretation was raised by historian Peter Gibbons. He challenged historians to move beyond ideas of national identity and pay more attention 'to the world's place in New Zealand'. 9 This is part of a wider rejection of the nation as the key lens of historical enquiry. Transnational histories link places rather than nations. Along with this, the work of postcolonial scholars links peoples and local identities while preserving difference. 'British World' histories, as suggested above, write back from the edge to the centre or the metropolis. These approaches destabilise ideas such as national identity or imperial 'Britishness'. Many historians have taken up these challenges and they are often felt more keenly in former imperial outposts such as New Zealand. The latest edition of the Oxford History of New Zealand encapsulates these approaches, which are also highlighted by its thematic, non-chronological structure and its multicultural and multi-gendered authors. ${ }^{10}$ Much New Zealand history writing is now decentred and postcolonial. However, it also tends to be deaf to how New Zealanders heard the sounds of empire as they blared from films, records, and radio.

The roles of listening in the formation of the public self as individual, citizen, and subject have been explored by scholars such as Kate Lacey and Susan Douglas. ${ }^{\text {II }}$ Simon Potter's work on the construction of Britishness via the BBC as institution and international broadcaster places radio at the centre of imperial control and domination. ${ }^{12}$ Nevertheless, this work also replicates the hub and spoke model of empire and emphasises the BBC as a media institution rather than an audible experience. In this account, the BBC broadcasts from the centre to the extremities who tend to be written as passive receivers.

When we listen, we are the subjects at the centre of our hearing. New Zealand was (and is) a listening subject in its own right and New Zealanders heard radio's meanings from their own perspectives at the centre of radio reception and hearing. Postcolonial perspectives anatomise these multiple discourses and identities and allow the colonised to establish cultural and political identities on their own terms. The 'post' here is about engaging with the ongoing effects of colonisation rather than reading its funeral rites. ${ }^{13}$ As the Australian poet Roberta Sykes asked in her I996 poem "Post Colonial Fictions": 'Have I missed something?/...Have they gone?'I4

They (we) have not gone and I acknowledge that I write from a non-Māori perspective. These words are my own and not an attempt to tell other people's stories. A popular Māori proverb is 'Naku te rourou nau te rourou ka ora ai te iwi', which translates as 'With your basket and my basket the people will thrive.' The idea is that sharing stories and histories encourages understanding and mutual growth. Listening to our varied stories and perspectives is an important aspect of implementing the Treaty of Waitangi and listening is at the core of this story. The first section traces New Zealand radio as an imperial project and the second listens in on Māori radio and the use of Te Reo as a critique of that project. ${ }^{15}$ 


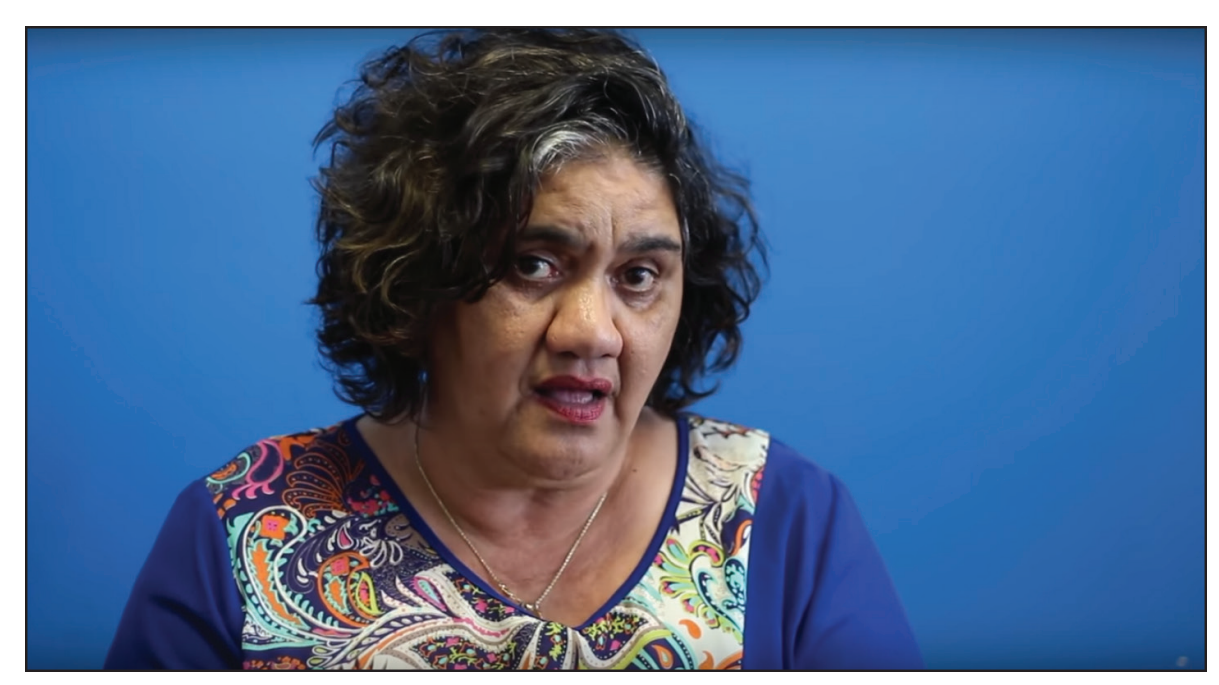

Figure 2. Dr Ella Henry briefly outlines the effects and consequence of colonization.

\section{Radio and Empire}

New Zealand as a nation state was born imperial. The I840 Treaty of Waitangi established a partnership between Māori and the British Crown. The Treaty is seen as a foundational text for New Zealand akin to the American Declaration of Independence or the British Magna Carta. ${ }^{16}$ Its mythology permeates all aspects of modern New Zealand life including broadcasting. The Treaty is ambiguous, multi-layered, and admits multiple readings. The ambiguity is quite literal as it exists in two versions, one in Māori and the other in English. Much of New Zealand's history is a continuing process of translation and the Treaty is important for the story of radio in New Zealand.

The country formally became a British Crown colony in I84I, was granted Dominion status in I907 and achieved political autonomy by passing the Statute of Westminster in I947. The English Monarch is still the constitutional head of state. The national flag still carries a Union Jack, which symbolises the role of the monarchy as well as many other things connected with the country's history as part of the British Empire. Politically, economically and culturally, New Zealanders looked to Britain as 'home' for many years. ${ }^{\text {I7 }}$ Zealandia was personified as a dutiful and loving daughter of Britannia and New Zealanders were devoted in their filial zeal. Since I945, this relationship has become more complicated. Britain's entry into the European Economic Community I973 is generally seen as a major turning point in New Zealand's relationship with Britain. One historian described it as 'the tectonic plates of our world shifting.' ${ }^{18}$ After this act of parental betrayal, New Zealand looked to a wider world especially to the Pacific, Asia and North America for new markets, treaties, alliances, immigrants, and cultural exchanges. This broad sketch is the context for radio in New Zealand.

During I 876 , New Zealand was plugged into the technological data flows of empire when a telegraph connection with Australia was made. ${ }^{19}$ The development of wireless telegraphy raised many questions, possibilities, and some fears. The new technology was discussed at the Imperial Conference of I9O2 mainly in terms of naval communication and it was noted that there was need for "some regulation to prevent "interference" and to insure control in 
time of war.' ${ }^{20}$ The New Zealand government was quick to react and passed the first legislation in the world regarding wireless telegraphy in 1903.

The single page of the I903 Wireless Act allowed the government to set up wireless telegraphy stations and threatened any unauthorised station operators with confiscation of their equipment and a fine of up to $£ 500 .^{2 I}$ The main point of these harsh penalties was to maintain the smooth functioning of national and imperial government. This control was made explicit by the Post and Telegraph Act of 1908 that restated the contents of the I903 Act but brought wireless telegraphy under the direct control of the Minister in charge of the Postal and Telegraph Department. ${ }^{22}$ Imperial security was the main issue here as was made clear in I9I3 when a I6-year-old was taken to court for operating an unlicensed wireless device. The Crown prosecutor stated: "What the boy was doing for his own instruction might be done by others for reasons serious to the country and Empire such as the interception of wireless messages from overseas. Such plots might produce results of the utmost gravity.' ${ }^{23}$ In the event the youth was discharged but with the outbreak of war in I9I4, all amateur wireless operations were banned and severe penalties were imposed on any operators who were caught making illegal transmissions. ${ }^{24}$

New Zealand wireless was militarised between I9I4 and I9I8. In addition, a unit was specifically formed to use the new technology. The New Zealand Wireless Troop numbered only I79 personnel and operated in the Mesopotamian and Persian Campaigns from I9I6 until early I9I8 when it was sent to France and merged with the New Zealand Divisional Signallers. ${ }^{25}$ The Wireless Troop monitored wireless transmissions from all the powers involved in the campaign both allied and enemy. They pinpointed other radio stations and gathered intelligence about troop positions, movements, supplies and strengths. One officer stated that it was as if 'every

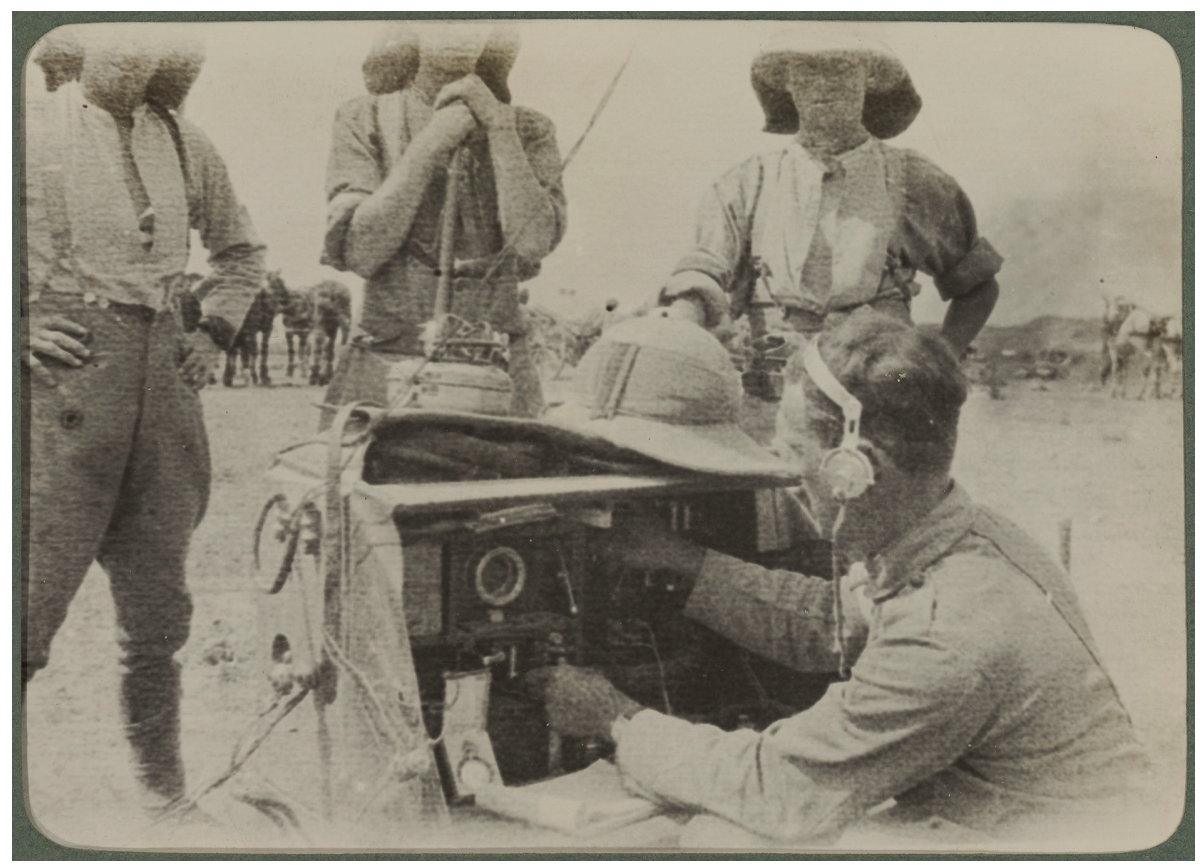

Figure 3. Members of the New Zealand Wireless Troop operating a portable radio in Mesopotamia c.1917. Hocken Collections Uare Taoak o Hakena, P1993-024-022b. 
enemy message arrived at Intelligence as surely and certainly as if it had been addressed to them. ${ }^{26}$ New Zealanders were at the nexus of this cutting edge intelligence technology being used to further imperial ambitions.

The New Zealanders involved in wireless work overseas during the war learned about new technologies and developments from the contacts they made with other Allied operators as well as the education provided by the army. They also acquired these new technologies by fair means or foul. ${ }^{27}$ The knowledge, skills, and equipment they brought back to New Zealand after the war were the basis for development of radio broadcasting during the early I920s.

These ex-servicemen (and they were all men) along with a motley collection of academics, amateurs, tinkerers, and technicians established broadcast radio in New Zealand during the early ig2os. Some formed societies and some worked alone. The establishment of the Radio Broadcasting Company (RBC) (I925-32) by government regulation in I925 began the systematic organisation of radio in terms of content and broadcasting schedules. Over the next decade, government interest in and control over radio became stronger and tighter as the new and exciting medium was quickly embraced. Radio licences helped fund broadcasting and these increased exponentially during this time. In I925, there were four. By 1935 there 152,800 in a country of I.5 million. ${ }^{28}$ The I93I Broadcasting Act replaced the RBC with the New Zealand Broadcasting Board (NZBB) that followed the BBC model. Some 25 radio stations (the B stations) remained independent until I935 when the government took control of all radio under the New Zealand Broadcasting Service (NZBS). The NZBS became the New Zealand Broadcasting Corporation (NZBC) in 1962 , which was in turn dissolved in 1975 when separate entities were established for radio and television. ${ }^{29}$ Broadly speaking New Zealand radio followed the British model of state administered public broadcasting. Radio linked New Zealand with the world and fostered a sense of Britishness.

Being British and being a New Zealander, and being part of the empire were identities that official discourse and ceremonies such as Anzac Day, the annual day of military remembrance, were built around. The sounds of Britain, still the 'home country' for many New Zealanders between the wars, were heard with interest. Lorraine Russell never missed the BBC news as a child 'with the spine-tingling sound of Big Ben followed by the announcer's voice crackling over the distant airways. ${ }^{30}$ Events such as the Royal Jubilee of 1935 and the abdication of King Edward VIII in 1936 were followed by New Zealanders on shortwave. The technology of shortwave strengthened and extended New Zealanders' sense of participation in the 'imagined community' of the British Empire in a direct way through the sense of simultaneity that radio generates. For Lorraine, and many around the world, the sound of Big Ben's chimes became a metonym for Britain and by implication the British Empire.

The last major imperial occasion between the wars that New Zealanders heard through radio was the Coronation of King George VI on I2 May I937. This was the first Coronation of an English monarch to be broadcast on radio and it was a huge undertaking involving hundreds of miles of cable, 58 microphones, I2 tons of equipment and sixty BBC engineers, 'those inside the Abbey doing their job in full morning dress. ${ }^{3 \mathrm{I}}$ The coronation was marked by speeches, parades and banquets in New Zealand. Many people then stayed up late listening to the ceremonies in 


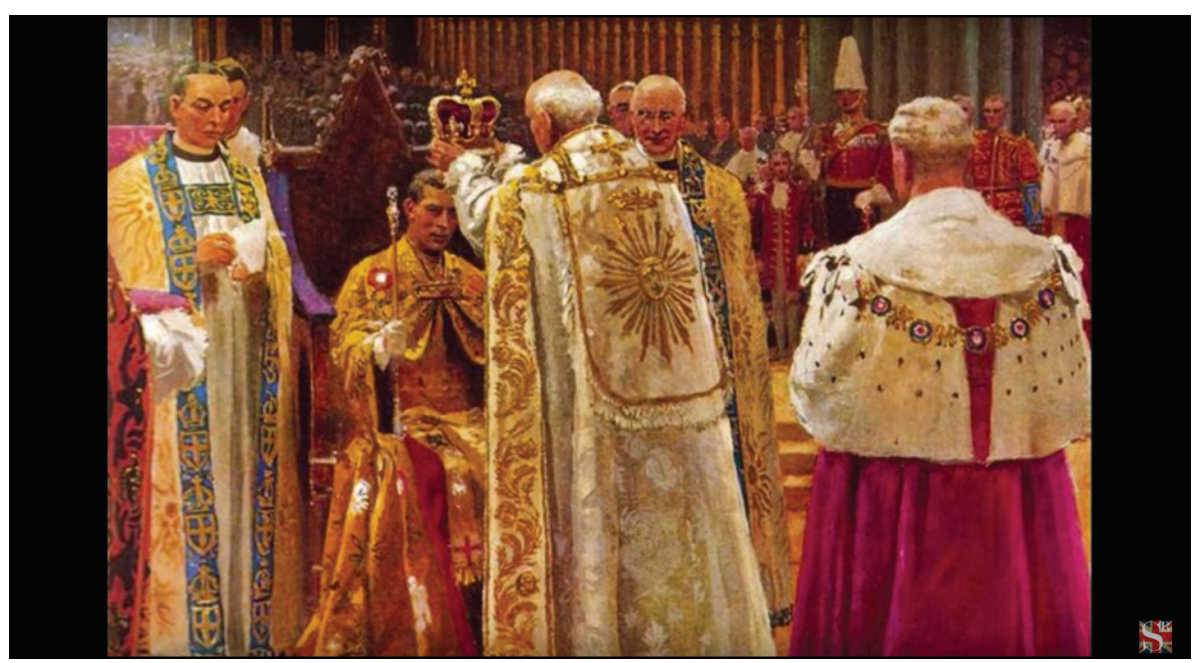

Figure 4. The 1927 Coronation radio broadcast that many, but not all, New Zealanders heard as the venerated voice of authority.

Britain being transmitted around the world on shortwave by the BBC Empire Service. 32 'Listener', the Christchurch Press' radio critic, playfully estimated that I,০০০,০০০ New Zealanders listened to the live broadcast before going on to paint an amusingly ironic picture of the fortunate listener sitting comfortably at home far away from the crush of the crowds 'who could, with the exercise of a little imagination, bring the gorgeous scenes into our own sitting rooms.' 33 The radio broadcasts united New Zealanders in the imperial imaginary that the Coronation signified. New Zealanders were not just 'one people' as New Zealanders, they were also one with the people of the Empire.

Broadly speaking until well into the I970s, radio sounded 'British'. Announcers were trained to speak correct or what was described as 'accepted English'.34 Concern with purity of language was part of a wider drive by elites, middle class, and official cultural gatekeepers to protect New Zealand from the dangers of American mass culture. Records, music, books, films, and radio serials were dangerous and defiling. 35 Radio was particularly dangerous as it brought such cultural and linguistic impurities into the house. Many cultural guardians warned the public of the menace. In I938 R. E. Besant of Trinity College of Music visited New Zealand to conduct the elocution examinations blamed radio as a source of American 'slang and useless, ugly, and often meaningless phrases. ${ }^{36}$ W.J. Mountjoy, a New Zealand teacher, voiced similar concerns and blamed mass culture in the form of new technologies such as the radio as the main culprit in the decline of the 'mastery of spoken English'.37 Radio in New Zealand was heard by some as a bulwark against the barbarities of modern mass, non-British culture. And it was only ever English that was heard on New Zealand radio.

This mission of cultural purity imbued public radio for many years especially after the reign of the patrician James Shelley (director from I936-I949) who embodied the Reithian ideal of cultural uplift. ${ }^{8}$ But New Zealand's culture was changing and it tended to be elites who clung to a sense of Britishness and a sense of the imperial when for most people it was a relic of the past. 39 
Post-I945 changes accelerated this process. New Zealand historian James Belich points to four drivers of post-war globalisation that took New Zealanders out into the world and brought the world into New Zealand. These were mass media, transport, communications and information. ${ }^{40}$ Immigration from Pacific, Asian, and other territories outside the traditional British sphere made for an increasingly diverse and cosmopolitan population in terms of ethnicity, culture, and religion.

New Zealand radio was radically transformed by the Telecommunication Act of I988, which deregulated what had formerly been a very tightly controlled media sector. Deregulation was an economic, cultural, and social revolution commenced in 1984 by the incoming Labour government. These changes arose from the neoliberal ideologies deployed by Ronald Reagan in the USA and Margaret Thatcher in Britain, among others. This international ideology affected all aspects of life in New Zealand. ${ }^{\mathrm{I}}$ Deregulation is often seen as the big bang of private radio in New Zealand. The formerly dominant British based 'public good' model of broadcasting was abandoned for a free market ethos. The consequences have (among other things) been a concentration of ownership and increased standardisation of radio styles, formats, and content leading to an increasingly homogenous commercial radio sector despite the increased quantity of stations..$^{2}$

But deregulation also provided opportunities and New Zealand's contemporary radio sector is rich and varied. Radio in New Zealand consists of a public broadcaster (RNZ) whose origins lie in the BBC model. Two companies own collections of tightly formatted and networked commercial stations that are marketed at tightly researched demographics. Several groups of independent and networked stations broadcast to Hindi, Chinese and Polynesian communities. There is a private Christian network of several stations and a community/access network, which relies on a combination of public funding and donations. There are also hundreds of micro broadcasters in the form of LPFM stations (Low Power FM) which have very local reaches of a kilometre or so. New Zealand has a lot of radio and New Zealanders spend a lot of time listening to it. ${ }^{43}$ New Zealand radio is diverse and reflects the country's pluralistic population living increasingly 'transnational lives' as historian Philippa Mein Smith phrases it. 44 The commercial and public networks dominate radio listening and despite New Zealand's rich mix of languages and cultures, English is the predominant language heard on the airwaves. This is an aspect of the country's British/imperial heritage and yet the Waitangi Treaty, the nation's founding document, calls for partnership. The next section examines how Māori radio has developed as a response to the Treaty and as an immanent critique of New Zealand's imperial origins.

\section{Māori Radio and Empire}

Sound matters and the sound of words can matter very much where empire has erased and silenced indigenous languages. New Zealand DJ Alex Behan illustrated this in 2016 when he sparked a media controversy with an online article about the pronunciation of just one word.45 That word - Hauraki - is the name of the radio station he worked for. Radio Hauraki launched 
in I966 as a pirate station rebelling against the then dominant state broadcaster, the New Zealand Broadcasting Corporation (NZBC). ${ }^{4}$ Following the lead of Britain's Radio Caroline, the station's staff took a ship into international waters and broadcast from the Hauraki Gulf hence the station's name. Fifty years after its rollicking, piratical, and controversial genesis, Radio Hauraki is a staid and typical rock music formatted station with an audience of 'white male skewed men (...) between the age of 25 and 44.47 White New Zealanders are known as Pākehā and Pākehā pronunciation of Māori words is often incorrect. From the start, the 'Hauraki' in Radio Hauraki had been pronounced the White way as 'Howrakkey'. The Māori pronunciation is as 'Hoeraki'. Alex Behan had objected to Hauraki's management about this linguistic mangling many times but was told that the Pākehā version was an integral part of the station's branding and must not be altered. $4^{8}$ This news outraged many people.

The resulting media reaction caused NZME, Radio Hauraki's parent company, to backtrack and issue instructions that 'Hauraki' was to be pronounced on air as per the Māori language rather than the Pākehā version.49 Behan, however, lost his job for going public about this.

Māori (along with Sign) is an official language of New Zealand. The correct pronunciation of Māori words is very important in modern New Zealand culture and media and is symbolic of a novel set of emergent postcolonial identities. The traditional, colonial/imperial policy had been to discourage the use of Māori language in public life. It was not taught in schools and formed a minor, tokenistic part of official public life.

Māori, both the people and the language, were heard on radio from the I920s as broadcasting became systematically organised and structured but not as autonomous and equal partners. Māori singers, musicians, and speakers performed live in radio studios as part of the day-to-day programming..$^{\circ}$ In I928, J. F. Montague, an Auckland speech teacher began regular broadcasts on Māori pronunciation. Hare Hongi (Henry H. Stowell) of Nga Puhi descent took over these in

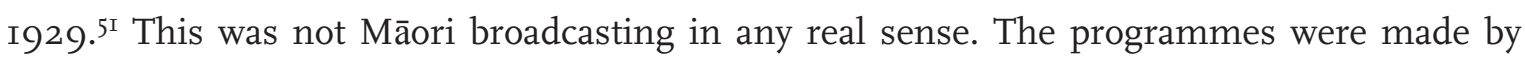
Pākehā and they were aimed at Pākehā. The language broadcasts were normative and designed

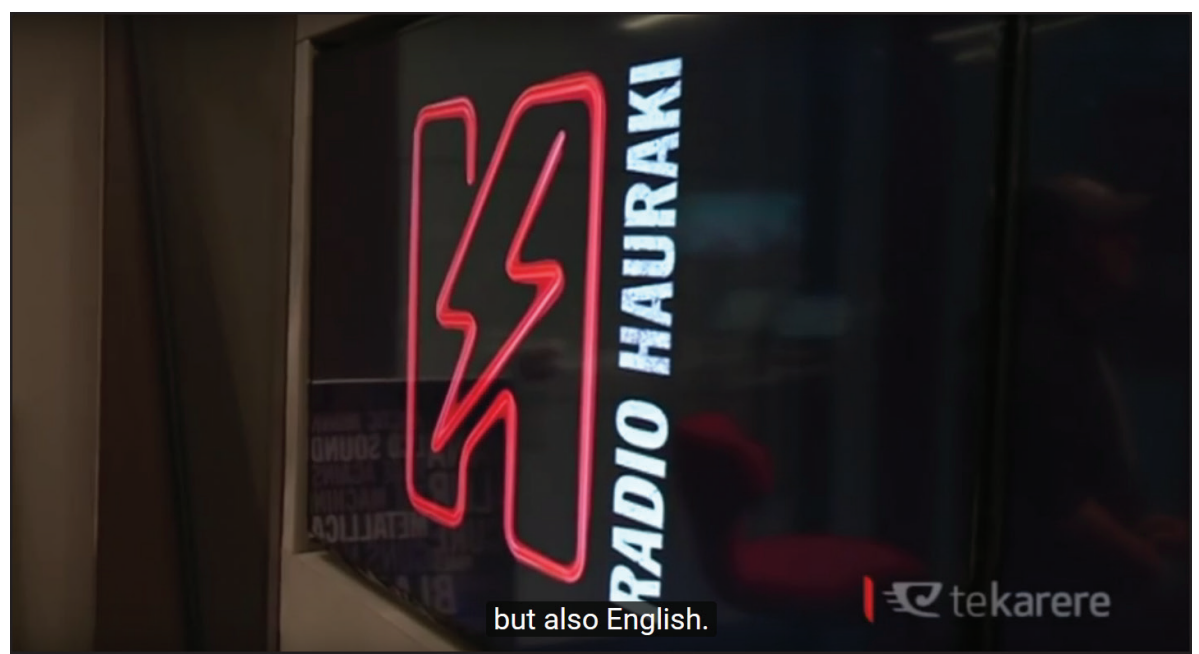

Figure 5. The Radio Hauraki pronunciation imbroglio as reported by TVNZ Māori news show "Te Karere" in 2016. 
to be educational. Montague's initial motivation was entirely didactic: 'Some of the common mispronunciations, many of them in fact, are atrocious, and it is time something was done about it.' ${ }^{2}$ Just as speech teaching of English was normative and didactic, the broadcasting of Māori pronunciation was designed to be instructional and corrective rather than to raise awareness of the culture and language itself.

A typical example of the imperial attitude to Māori can be seen in a national broadcast from I928. The Wellington station 2YA, the hub of the broadcasting network owned and run by the Radio Broadcasting Company ( $\mathrm{RBC}$ ), marked the eighty-eighth anniversary of the signing of the Treaty of Waitangi with a two and half hour special programme entitled 'A Radio Pageant of the Māori People'. This imperial extravaganza was relayed by the three other stations in the network across the country. It was also repeated the following night at a time when listeners in Australia and the Pacific Islands could tune in. In six scenes, the Pageant illustrated the course of Māori history from their arrival to the present day. The second section, 'The Dawn of a New Day', is a colonial text par excellence. It was about the European conquest of the nineteenth century which saw thousands of Māori die from disease and warfare, their culture and religion shattered, and their land confiscated whether through simple theft, rigged court proceedings, or at the point of a bayonet. The RBC's magazine, the Radio Record preferred this phrasing:

Here we have the coming of the missionaries, the sewing of the seeds of Christianity followed, unhappily by the misunderstandings which led to the tragedies of the Māori Wars. Happily the days of strife have long since passed away, and today the two races live as one in a friendly relationship beneath the Union Jack sharing the privileges and the responsibilities of a common citizenship. 53

The following section concerned Māori and World War One. Between musical items, Prime Minister Gordon Coates spoke approvingly of how Māori 'recognising their responsibilities as British subjects by virtue of the Treaty (...) offered the services of their sons to fight the common foe in defence of the Empire. ${ }^{.54}$ After two more sections that depicted the peace and happiness of the present day, the Pageant concluded on a cheerful note with 'Home, Sweet Home' and the National Anthem.

Listeners seemed to enjoy the Pageant. It was described as 'Outstanding in merit and appeal' and the RBC was praised for the organisation, planning, and thought that had gone into such a long and complex live radio performance. ${ }^{55}$ Another review called it interesting and comprehensive and praised the Wanganui Concert Party for their admirable performances; 'Hakas, pois, and orations were rendered delightfully. ${ }^{56}$ It was suggested that 'the fullest exploitation of Māori talent' should be considered by the RBC to produce programmes of similar quality. ${ }^{57}$

The performances by Māori were not attempts to invigorate or arouse awareness of the culture. They represented colonial attitudes to the Māori as naturally musical performers. They were presented as 'quaint natives' whose colourful stylings of European based musical forms were part of New Zealand's national heritage but were in no way any alternative to the performances of high and middle brow European music that radio stations habitually broadcast. 


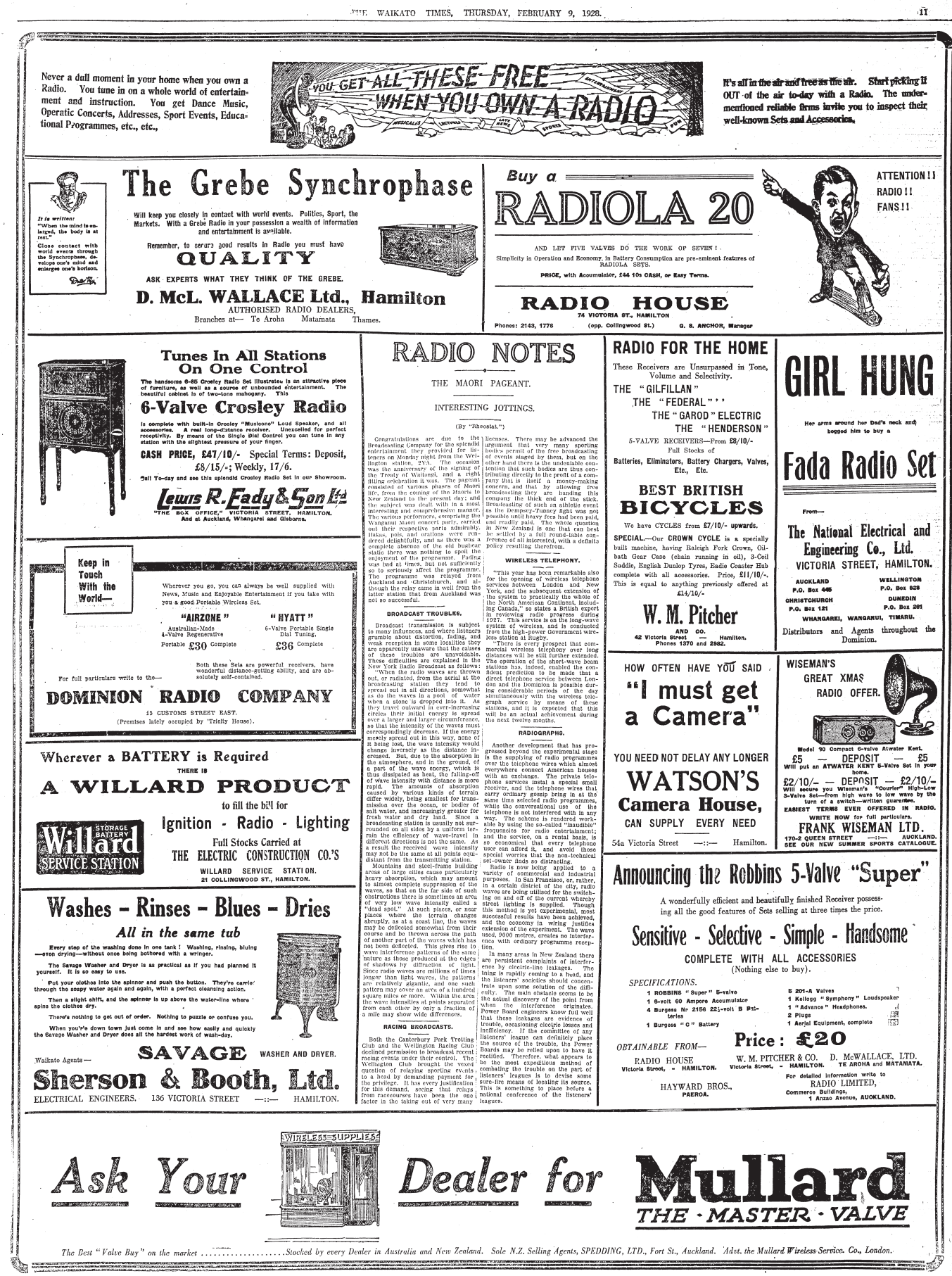

Figure 6. Radio columnist 'Rheostat' gave the Pageant a good review in his weekly radio column which appeared surrounded by a full page of advertisements for radios, cameras, and bicycles. The Waikato Times, 9 February, 1928, p. 11.

An editorial in the Radio Record stated that: 'Suitably enough, the pageants will be associated with the Māori race, whose poetic and musical genius, in association with their romantic past, promises entertaining evenings. ${ }^{58}$ The article refers to 'our romantic native race' in paternalistic tones that indicate the attitudes of the time about Māori culture. The popularity of the radio broadcasts of Māori performers between the wars and after indicated the public interest in a 
sonic imagining of Māori culture that was non-threatening, sentimentalised, and informed by imperial and romanticised ideas about Māori culture. Māori were heard on radio between the wars to bolster the idea of New Zealanders as one people rather than as a diverse assemblage of groups and cultures whose interests and needs often diverged. This listening could be heard as a form of comfort for the Pākehā majority and a deafness to the fissures and divides that ran through society. This radiophonic version of New Zealand's history broadcast the idea of imperialism, as it was understood by New Zealanders as radio became an important part of daily life and involved in shaping the national imagination along the lines suggested by Benedict Anderson. Waitangi Day is an important annual holiday in New Zealand that marks the signing of the Treaty.59 The RBC's I928 Waitangi Day Pageant signified an idea of the Treaty as uniting colonisers and colonised as one people. This was the imperial soundscape of unity and harmony, literally in the case of the musical items. This vision also reflected how the imperial centre viewed New Zealand.

The Māori language is heard all over contemporary New Zealand radio even if it amounts to only the use of simple phrases and greetings. It is a sign of the cultural independence and widespread rejection of imperial racial attitudes. This is a slow and continuing process for New Zealand culture and media; 'ka whawahi tonu matou', or 'struggle without end' as the scholar and activist Ranganui Walker entitled his groundbreaking history of New Zealand from a Māori perspective. ${ }^{60}$ The all-embracing model of Britishness, which dominated New Zealand culture for much of its history either silenced other voices or relegated them to the status of exotic curiosities.

The recovery and revival of the language began in the I970 and gained pace during the I980 as part of a general regrouping and revitalising of Māori culture and influence known as the 'Māori Renaissance'. ${ }^{6 I}$ In New Zealand, as elsewhere, radio and other media have been important preserving an indigenous language in the face of the imperial onslaught of English. ${ }^{62}$ An important aspect of this Renaissance was the development of a national radio network run by Māori for Māori. Te Whakaruruhau o Ngā Irirangi Māori (The Māori Radio Network) is an independent network of 2I stations spread across New Zealand that broadcast in Māori and play Māori music. The stations are funded through a combination of sponsorship, advertising, and government finance. The latter is dependent on the amount of Māori content that is broadcast. ${ }^{6} 3$ Māori radio, that is radio made by Māori for Māori listeners, emerged as a powerful force during the I980s but the struggle was long and difficult. ${ }^{64}$

The modern network of Māori stations was built from a community level by Māori people in the face of much opposition, and perhaps even more damaging, indifference from the wider society. Cyril Chapman, manager of the first Māori station established said that:

The most important thing to come from Iwi radio, is that Māori have proved that real people can do it (...) it's come from the people on the ground who listen to us, and can tune into us, and feel the things that we're talking about, and be part of it. The commitment is to the language, it will never die. ${ }^{65}$ 
For those who understand Te Reo listening to a Māori radio station is, among many other things, in effect a form of anti-imperial activity. In a postcolonial society like New Zealand, imperial and colonial power is stitched into the fabric of the society. Media made by and for Māori goes against the imperial grain and opens up new ways of hearing (and seeing) which link to other postcolonial societies and indigenous peoples who are also dealing with the all too often fatal consequences of imperial conquest. They bring the world into New Zealand through these global linkages.

The Māori Network stations are based in Māori communities and broadcast to their local areas. New Zealand's public radio broadcaster, RNZ, covers the entire country. RNZ is guided by a charter, which sets out the organisations' principles and goals. One of these is that it must 'reflect New Zealand's cultural identity, including Māori language and culture.' 66 This principle has been vigorously applied since 20I7 when the Statement of Performance Expectations for 20I8 spelled out how Te Reo was to be incorporated into RNZ's activities. These measures include:

Te Reo Māori being heard in almost every RNZ news bulletin - reporters have chosen to sign off in te reo [sic] to underline their desire to share the language with as many New Zealanders as possible.

On-air staff training in te reo [sic] to develop their knowledge and ability to speak and in time this education programme will be made available to all RNZ employees.

Māori staff taking the lead in live programming on days of national significance (e.g. Waitangi, Anzac). ${ }^{67}$

Also indicating how modern radio is a multimedia medium, the RNZ website will be a 'significant platform' for the promotion of the language and culture. RNZ Chief Executive Paul Thompson defended the strategy by invoking the Charter principle mentioned above and concluded his comments appropriately enough with a Māori proverb:

This seems a fairly basic undertaking for a public broadcaster that wants to reflect all that is unique and important to a nation of many parts but with a single destiny. As the whakataukī (proverb) says: 'Nāu te rourou Nāku te rourou ka ora ai te iwi. With your basket and my basket the people will live.' 68

The decision by the public broadcaster to use Māori words across its programming generated some controversy but most commentators were in favour of the move. ${ }^{69} \mathrm{RNZ}$ is obligated by its charter to foster a sense of national identity and the sound of Te Reo is heard as part of that identity.

This sea change in the role of the Māori Language explains the backlash against Radio Hauraki's laxness in the pronunciation of the station's name. Knowing Te Reo and saying it correctly are bound up with the idea of being a New Zealander. Over the last few years, demand for Māori language classes has outstripped supply as many New Zealanders now see Te Reo as 
a desirable signifier of national identity. $7^{\circ}$ This idea of identity seems to have come a long way from being a subject of the 'Imperial Government' James Allen served. However, the revival and growth of the language have imperial origins in that they stem from the Treaty of Waitangi signed in $\mathrm{i} 840$.

The Treaty exists in two versions: one in English and the other in Māori. This has led to difficulties. Article Two (in the Māori version) grants Māori tino rangatiratanga over their taonga which translates as 'unqualified exercise of their chieftainship' over their lands and 'treasure'. These treasures include resources, forests, and animals and so on but also intangibles such as language. The English version uses the phrase 'exclusive and undisturbed possession' for tino rangatiratanga. These are different concepts which have given rise to various interpretations but all acknowledge the centrality of the document as a basis for New Zealand's national imaginary. ${ }^{\mathrm{I}}$

Calls to 'honour the Treaty', that is take its contract between Māori and Crown seriously, were a major part of the Māori renaissance. The Māori language is seen as a 'taonga' or treasure and therefore is guaranteed preservation under Article 2. While the English version of the Treaty reads as a typically all-conquering imperialist text (possessions can be bought or taken), the Māori version preserves indigenous authority over the land, resources, and the language (chieftainship is bestowed, not purchased). In a sense, the Treaty is both a colonising and a decolonising text. It undermines imperial power while seeming to acquiesce to it. The language as taonga is at the heart of this decolonising process. Speaking Māori, or at the very least pronouncing it correctly, is a way of being a New Zealander and the media are expected to follow this as part of a commitment to the terms of the Treaty.

Media historian Kate Lacey discusses the importance of 'listening out' for a functioning public sphere, which is the very area that public broadcasters such as RNZ operate within. She argues for it as an 'ethical obligation to listen out for otherness' in terms of opinions and voices that can be challenging and uncomfortable..$^{22}$ Some listeners found the use of Te Reo on public

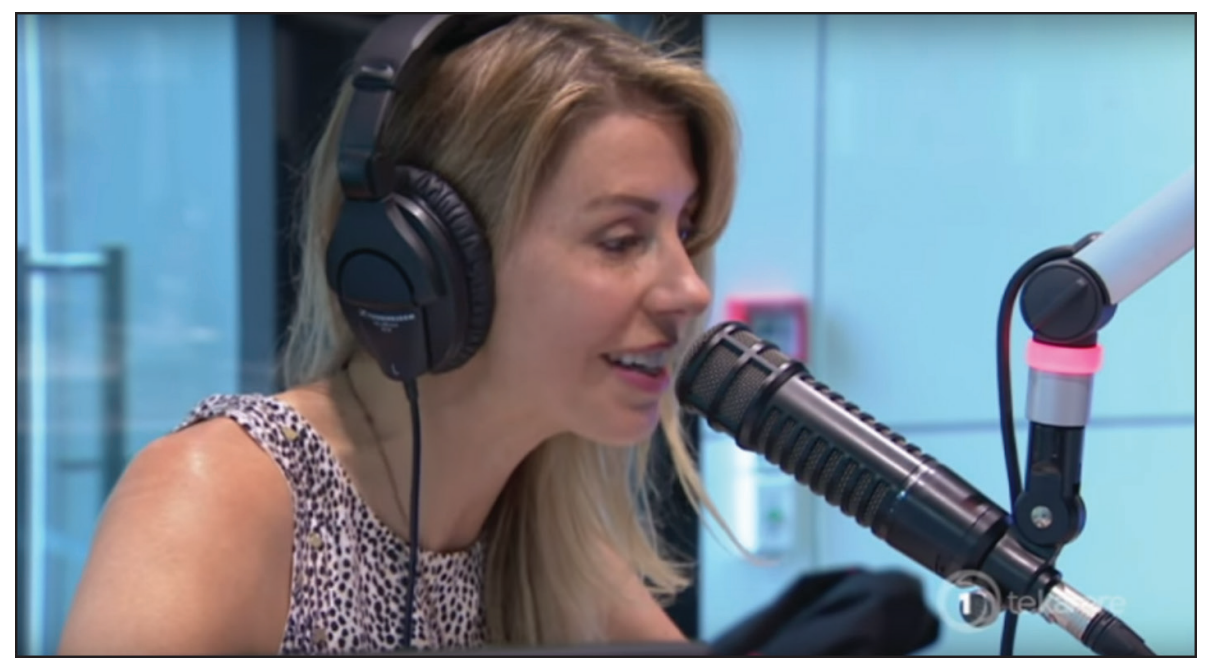

Figure 7. News show "Te Karere" by TVNZ Māori explores the aftermath of the Radio Hauraki pronunciation imbroglio 5 months on and the burgeoning of Te Reo Māori across New Zealand's media and culture. 
radio 'challenging and uncomfortable' in the sense that it undermined their sense of New Zealand as an English speaking country, an English land in effect.73 They were still expecting to hear imperial radio rather than the postcolonial version that is unique to New Zealand by its being based on the principles of the Treaty of Waitangi.

The symbolism of learning Māori, or at least pronouncing it correctly, is central to the contemporary idea of New Zealand's identity as an independent nation/culture that has shaken off the British imperial chains. As New Zealand approaches the centenary of radio, pronouncing Māori words such as 'Hauraki' the 'Pākehā way' is heard as re-broadcasting an outdated imperial and British identity that is irrelevant to the country's increasingly pluralistic and multi-cultural society.

\section{Notes}

I. Stephen Smith, The Samoa (N.Z.) Expeditionary Force 1914-1915 (Wellington: Ferguson and Osborn, I924), 7; Ian McGibbon, ed., The Oxford Companion to New Zealand Military History (Auckland: Oxford University Press, 2000), 475-476.

2. Janeen Love, "Telling the Story of the I9I4 Occupation of Samoa," https://wwioo.govt.nz/ telling-the-story-of-the-I9I4-occupation-of-german-samoa.

3. New Zealand Herald, i September, I914, 7.

4. Auckland Star, I September, I9I4, 6; Evening Post, 2 September, I9I4, 6.

5. Daniel R. Headrick, The Tentacles of Progress: Technology Transfer in the Age of Imperialism, 1850-1940, New York: Oxford University Press, I988), I26-I30; Priya Satia, "War, Wireless, and Empire: Marconi and the British Warfare State, I896-I903," Technology and Culture 5I, no. 4, (2010): 829-53; Heidi J. S. Tworek, "How Not to Build a World Wireless Network: German-British Rivalry and Visions of Global Communications in the Early Twentieth Century," History and Technology 32, no. 2 (2016): I78-200.

6. Benedict Anderson, Imagined Communities: Reflections on the Origin and Spread of Nationalism (London: Verso, 2006).

7. There is a large body of work on Māori history from many viewpoints. A good general overview is: Atholl Anderson, Judith Binney and Aroha Harris, Tangata Whenua: An Illustrated History (Wellington: BWB, 20I4); This recent article highlights the issues involved in writing this history: Alice Te Punga Somerville, "Two Hundred and Fifty Ways to Start an Essay about Captain Cook," New Zealand Journal of History 53, no. I (2019): $3-49$.

8. Katie Pickles and Catharine Coleburne, “Introduction: New Zealand's Empire,” in New Zealand's Empire, ed. Katie Pickles and Catharine Coleborne (Manchester: Manchester University Press, 20I6), I.

9. Peter Gibbons, "The Far Side of the Search for Identity: Reconsidering New Zealand History," New Zealand Journal of History 37, no. I (2003): 47.

Io. The volume's introduction explicitly lays out how these approaches inform the book. See: Giselle Byrnes, "Introduction: Reframing New Zealand History," in The New Oxford History of New Zealand, ed. Giselle Byrnes, (Melbourne: Oxford University Press, 2009), I-I8.

II. Kate Lacey, Listening Publics: The Politics and Experiences of Listening in the Media Age (Cambridge: Polity Press, 2013); Susan J. Douglas, Listening In: Radio and the American Imagination (Minneapolis: University of Minnesota Press, 2004).

I2. Simon Potter, Broadcasting Empire: The BBC and the British World, 1922-I970 (Oxford: Oxford University Press, 2012).

I3. Eric Pawson, "Postcolonial New Zealand?" in Cultural Geographies, ed. Kay Anderson and Faye Gayle (Melbourne: Addison Wesley, I990), 25-50.

I4. Roberta Sykes, Eclipse (St Lucia, Queensland: University of Queensland Press, I996), I6.

I5. The phrase 'Te Reo' means 'The language' and the phrases are used interchangeably.

16. The literature on the Treaty is vast. The usual place to start is: Claudia Orange, The Treaty of Waitangi (Wellington: Bridget Williams Books, $2^{\text {nd }}$ ed., 20II) 
I7. For a classic example of this imagining see: Alan Mulgan, Home: A New Zealander's Adventure (London: Longmans, Green and Co., I927).

I8. Erik Olssen', “The Shaping of a Field," in Disputed Histories: Imagining New Zealand's Pasts, ed. Tony Ballantyne and Brian Moloughney (Dunedin: Otago University Press, 2006), 228.

I9. Eric Pawson and Neil C. Quigley, "The Circulation of Information and Frontier Development: Canterbury 1850-I890," New Zealand Geographer 38, no. 2 (1982): 65-76; A.C. Wilson, Wire a Wireless: A History of Telecommunications in New Zealand 1890-1987 (Palmerston North: Dunmore Press, 1994), 49-52.

20. New Zealand Government, Appendices to the Journals of the House of Representatives, Session I, A-07 (1903): 30.

2I. New Zealand Government, New Zealand Statutes (1903): 28.

22. Wilson, Wire \& Wireless, 92; Chris Foote, "Broadcasting in New Zealand and the Role of the Post Office: Part One," The Mail Coach: Journal of the Postal History Society of New Zealand 47, no. 2 (2010): 74.

23. Evening Post, I4 August, I9I3, I0.

24. Patrick Day, The Radio Years: A History of Broadcasting in New Zealand Volume One (Auckland: Auckland University Press, I994), 3I.

25. Atom, "Wireless", The Kia Ora Coo-Ee: The Magazine for the Anzacs in the Middle East, 1918 (Sydney: Angus \& Robertson Facsimile, I98I), 2; H.T.B. Drew, The War Effort of New Zealand (Auckland: Whitcombe and Tombs, I923), xxi-xxii; C.G. Powles, H.G. Alexander, and H.A. Lockington, Official History of the New Zealand Engineers During the Great War 1914-1919 (Wanganui: Evans, Cobb \& Sharpe, 1927), 299-303; Day, The Radio Years, 30-33; Wilson, Wire Q Wireless, IIO-II3.

26. Keast Burke, ed., With Horse and Morse in Mesopotamia: The Story of Anzacs in Asia (Sydney: A. \& N.Z. Wireless Signal Squadron History. Committee, 1927), 37.

27. John Herbert Hall, The History of Broadcasting in New Zealand 1920-1954 (Wellington: Broadcasting Corporation of New Zealand, I980), 4; Ian Dougherty, Ham Shacks, Brass Pounders Q Rag Chewers: A History of Amateur Radio in New Zealand (Upper Hutt: New Zealand Association of Radio Transmitters in association with Historical Branch, Dept. of Internal Affairs, I997), 22.

28. G. T. Bloomfield, New Zealand: A Handbook of Historical Statistics (Boston, Mass.: G. K. Hall, I984), 261.

29. For overview histories of this period see Hall, The History of Broadcasting; Peter Downes and Peter Harcourt, Voices in the Air: Radio Broadcasting in New Zealand, a Documentary (Wellington: Methuen, 1976); Day, The Radio Years; Patrick Day, Voice Q Vision: A History of Broadcasting in New Zealand Volume Two (Auckland: Auckland University Press, 2000).

30. Lorraine Russell, Family Hold Back: A 1930s Childhood (Steele Roberts: Wellington, 200I), 80.

3I. Paddy Scannell and David Cardiff, A Social History of British Broadcasting: Volume One 1922-1939, Serving the Nation (Oxford: Blackwell, I99I), 284.

32. Simon Potter, Broadcasting Empire: The BBC and the British World 1922-1970 (Oxford: Oxford University Press, 2012), 94.

33. Press, I5 May, I937, I9.

34. Arnold Wall, New Zealand English: A Guide to the Correct Pronunciation of English (Christchurch: Whitcombe \& Tombs, I938), i.

35. Day, The Radio Years, 252-253; Patrick Day, "American Popular Culture and New Zealand Broadcasting: The Reception of Early Radio Serials" Journal of Popular Culture 30, no. I (1996): 203-I4; James Belich, Paradise Reforged: A History of the New Zealanders From the 1880s to the Year 2000 (Auckland: Allen Lane, 200I), 25I-254.

36. Christchurch Press, 2 July, I938, 2 I.

37. Janet Soler, "Renegotiating Cultural Authority: Imperial Culture and the New Zealand Primary School Curriculum in the i930s", History of Education 35, no. I (2006): I8.

38. Ian Carter, Gadfly: The Life and Times of James Shelley (Auckland: Auckland University Press, I993), 2 II-48.

39. Daniel F. Millar, "Empire Men: New Zealanders in the British Colonial Service, c.I920-I970," New Zealand Journal of History 52, no. 2 (2018): I-22.

40. Belich, Paradise Reforged, 426.

4I. Ibid., 405-422.

42. Karen Neill and Morris W. Shanahan, ed., The Great New Zealand Radio Experiment (Southbank, Vic.: Thomson Learning/Dunmore Press, 2005).

43. NZ on Air, Where are the Audiences? 2018, https://www.nzonair.govt.nz/research/where-are-audiences-20I8. 
44. Philippa Mein Smith, A Concise History of New Zealand (Cambridge: Cambridge University Press, 2005), $244-246$.

45. Alex Beehan, "Don't Rock the Boat: The Real Reason Radio Hauraki Refuses to Pronounce its Own Name Right," The Spinoff, 28 July, 20I6, https://thespinoff.co.nz/media/28-07-20I6/dont-rock-the-boat-the-reason-radiohauraki-refuses-to-pronounce-its-own-name-right/.

46. Adrian Blackburn, The Shoestring Pirates (Auckland: Radio Pacific Press, 1994).

47. The Radio Bureau, About Radio Hauraki, https://www.trb.co.nz/brand-profiles/radio-hauraki.

48. Beehan, "Don't Rock the Boat".

49. Talisa Kupenga, "Radio Hauraki Fine Tunes Pronunciation," Māori Television, 5 December, 20ı6, https://www. Māoritelevision.com/news/regional/radio-hauraki-fine-tunes-pronunciation.

50. Some examples: Stratford Evening Post, 21 August 1926, 3; New Zealand Herald, 2 November, 1926, I3; Bay of Plenty Times, I5 July, I927, 2; Waikato Times, 29 October, 1927, 7.

5I. Day, The Radio Years, I23-4.

52. Ibid.

53. Radio Record, 3 February, 1928, 2.

54. Radio Record, Io February, I928, I6.

55. New Zealand Herald, 9 February, I928, I4.

56. Waikato Times, 9 February, I928, II.

57. Evening Post, I6 February, I928, 8

58. Ken G. Collins, Broadcasting Grave and Gay (Christchurch: Caxton Press, I967), 32.

59. Helen Robinson, "Making a New Zealand Day: The Creation and Context of a National Holiday," New Zealand Journal of History 46, no. I (2012): 37-5I.

6o. Ranganui Walker, Ka Whawhai Tonu Matou: Struggle Without End (Auckland: Penguin Books, 1990).

6I. Steven Webster, Patrons of Māori Culture: Power, Theory and Ideology in the Māori Renaissance (Dunedin: University of Otago, 1998).

62. Rangiānehu Matamua, Te Reo Pāho : Māori Radio and Language Revitalisation (PhD dissertation, Massey University, Palmerston North, 2006); Pamela Wilson and Michelle Stewart, ed., Global Indigenous Media: Cultures, Poetics, and Politics (Durham: Duke University Press, 2008).

63. "Accountability Documents," Te Māngai Pāho, accessed March I4, 20I8. https://www.tmp.govt.nz/accountability-documents; Rufus McEwan, "Iwi radio in the Era of Media Convergence: The Opportunities and Challenges of Becoming 'More Than Radio,” Pacific Journalism Review 25, no. I-2 (2019): I43.

64. Donna Beatson, "A Genealogy of Māori broadcasting: The Development of Māori Radio," Continuum: Journal of Cultural and Media Studies Io, no. I (I996): 76-93; Ian Stuart, "The Construction of National Māori Identity by Māori Media," Pacific Journalism Review 9 (2003): 45-58.

65. Beatson, "A Genealogy", 92.

66. RNZ, The Radio New Zealand Charter Te T tohinga o Te Reo Irirangi o Aotearoa, https://www.rnz.co.nz/about/ charter.

67. RNZ, Statement of Performance Expectations for the Year Ending 30 June 2018, https://www.rnz.co.nz/assets/cms_ uploads/000/000/083/Statement_of_Performance_Expectations_20I7_-_I8.pdf.

68. Paul Thomson, "Why RNZ is Dedicated to the Use of Reo," RNZ Comment and Analysis, 2 December, 20I7, https://www.rnz.co.nz/news/on-the-inside/345I70/why-rnz-is-dedicated-to-the-use-of-te-reo.

69. Glenn McConnell, "RNZ Listener Takes Offence to 'Over 'Māorification' of the Station," Stuff, I5 September, 20I7, https://www.stuff.co.nz/entertainment/tv-radio/96875989/rnz-listener-takes-offence-to-over-morification-of-thestation; RNZ Facebook, I December, 20I7, https://www.facebook.com/RadioNewZealand/posts/opinion-the-discussion-about-rnzs-use-of-te-reo-has-continued-in-the-media-this-/IoI5537085734373I/; BSA Decisions Ngā Whakatau a te Mana Whanonga Kaipāho, "HM and Radio New Zealand Ltd - ID2OI7-063," 6 September, 20I7, https://bsa.govt.nz/decisions/all-decisions/hm-and-radio-new-zealand-ltd-id20I7-063-6-september-20I7/.

70. Amber-Leigh Woolf, “Te reo Māori Courses Selling out as Fast as Tickets for Ed Sheeran or Adele," Stuff, 24 June, 20I8, https://www.stuff.co.nz/national/IO4736332/te-reo-mori-courses-selling-out-as-fast-as-tickets-for--ed-sheeranor-adele.

7I. This recent collection provides a wide range of views and perspectives on these roles: Rachel Bell, Margaret Kawharu, Kerry Taylor, Michael Belgrave and Peter Meihana, ed., The Treaty on the Ground: Where we are Headed, and Why it Matters, (Auckland: Massey University Press, 20I7). 
18 Tijdschrift voor Mediageschiedenis - 22 [2] 2019

72. Lacey, Listening Publics, I95.

73. Dave Witherow, "Haere mai? Everything is Far from ka pai!," Otago Daily Times, 24 November, 20I7, https:// www.odt.co.nz/opinion/haere-mai-everything-far-ka-pai; Colin Peacock, "Te reo on the radio too much for some," RNZ Mediawatch, 3 December, 20I7, https://www.rnz.co.nz/national/programmes/mediawatch/audio/ 2018623484/te-reo-on-the-radio-too-much-for-some.

\section{Biography}

Peter Hoar is a senior lecturer at Auckland University of Technology where he teaches radio studies and media history. His research interests are in the field of sound studies, particularly in history, listening practices and technology. His recent book The World's Din: Listening to Records, Radio and Films in New Zealand 1880-1940 is a cultural history of technologically mediated listening in New Zealand. 